\title{
Konsep Yuridis Hak Atas Kekayaan Intelektual Sebagai Harta Benda Wakaf
}

\author{
Rustam Magun Pikahulan
}

IAIN Parepare

Email: rustammagunpikahulan@iainpare.ac.id

\begin{abstract}
The focus of the study in this article is regarding the position of Intellectual Property Rights as the object of waqf from a juridical perspective. This article is included in the type of normative legal research because in this article the author makes law the subject of study, and the approach used in this article is of course the legal approach. Based on the results of the study and analysis, the authors conclude that, juridically, the Endowment of Intellectual Property Rights (IPR) has obtained legal legitimacy in Indonesia. In addition to being regulated in Law Number 41 of 2004 concerning Waqf, IPR waqf has also been confirmed in several laws in the field of IPR, both before the Waqf Law was issued and after the Waqf Law was issued. Intellectual Property Rights can be transferred as long as the transition does not conflict with the prevailing laws and regulations in society, including by way of waqf. This is because IPR is a movable intangible object, IPR material appears as a form of appreciation for intellectual activities that are born from human thought to create something new or original, both in the fields of science, technology, literature and the industrial sector.
\end{abstract}

Keywords: Waqf, Intellectual Property Rights

\section{Juridical Concept of Intellectual Property Rights as Endowments}

\begin{abstract}
Abstrak: Fokus kajian dalam artikel ini adalah menyangkut kedudukan Hak Atas Kekayaan Intelektual sebagai objek wakaf yang dilihat dari perspektif yuridis. Artikel ini termasuk dalam jenis Penelitian hukum normatif, karena dalam artikel ini penulis menjadikan undang-undang sebagai pokok kajian, dan pendekatan yang digunakan dalam artikel ini tentu pendekatan perundang-undangan. Berdasarkan hasil hasil kajian dan analisa maka penulis berkesimpulan bahwa, wakaf hak atas keakayaan intelektual (HAKI) secara yuridis telah mendapatkan legitimasi hukum di Indonesia. Selain diatur dalam Undang-Undang Nomor 41 Tahun 2004 tentang Wakaf, wakaf HAKI juga telah ditegaskan dalam beberapa undang-undang di bidang HAKI, baik sebelum Undangundang wakaf dikeluarakan maupun sesudah undang-undang wakaf dikeluarkan. Hak Atas Kekakayaan Intelektual bisa beralih sepanjang peralihan tersebut tidak bertentangan dengan ketentuan peraturan perundang-undangan yang berlaku dalam masyarakat, termasuk salah satunya dengan cara wakaf. Hal dikarenakan HAKI termasuk benda bergerak yang tidak berwujud, kebendaan HAKI muncul sebagai bentuk penghargaan atas kegiatan intelektual yang lahir dari pemikiran manusia untuk mewujudkan suatu yang baru atau orisinil, baik di bidang ilmu pengetahuan, teknologi, sastra maupun bidang industri.
\end{abstract}

Kata Kunci: Wakaf, Hak Atas Kekayaan Intelektual 


\section{A. Pendahuluan}

Wakaf adalah salah satu bentuk ibadah yang memiliki dimensi menahan atau berhenti atau diam di tempat atau tetap berdiri. ${ }^{1}$ Wakaf juga berarti menyerahkan sesuatu hak milik yang tahan lama zatnya kepada seorang nazdir (pemelihara atau pengurus wakaf) atau kepada suatu badan pengelola, dengan ketentuan bahwa hasil atau manfaatnya dipergunakan sesuai dengan ajaran Islam. Benda yang diwakafkan tidak lagi menjadi hak milik yang mewakafkan (waqif), dan bukan pula milik nazir, tetapi menjadi milik Allah (hak umat). ${ }^{2}$

Perkembangan pemaknaan wakaf berkembang dengan lahirnya peraturan perundang-undangan mengenai perwakafan di Indonesia, hal ini dimulai sejak dikeluarkannya Undang-Undang Nomor 41 Tahun 2004 tentang Wakaf serta Peraturan Pemerintah Republik Indonesia Nomor 42 Tahun 2006 tentang Pelaksanaan UndangUndang Nomor 41 Tahun 2004 tentang Wakaf. Terdapat perubahan pelaksanaan wakaf di Indonesia yang diatur dalam undang-undang tersebut. Salah satu yang mengalami perubahan serta perkembangan dalah mengenai harta benda wakaf sebagaimana yang terdapat dalam ketentuan Pasal 16 Undang-Undang tentan Wakaf. Pada pasal tersebut disebutkan bahwa harta benda wakaf terdiri dari benda tidak bergerak dan benda bergerak. Hak Atas Kekayaan Intelektual (HAKI) dalam undang-undang wakaf disebutkan sebagai salah satu jenis benda bergerak yang dapat diwakafkan menurut ketentuan pasal 16 undang-undang wakaf.

Konsep wakaf pada Peraturan Pemerintah Nomor 28 tahun 1977 tentang Perwakafan Tanah Milik masih identik dengan tanah milik. Akan tetapi maka dalam Undang-Undang Nomor 41 Tahun 2004, wakaf dikonsepkan mengandung dimensi yang sangat luas. Harta wakaf mencakup tidak bergerak maupun yang bergerak, yang salah satunya termasuk wakaf uang dan hak atas kekayaan yang penggunaannya sangat luas, tidak terbatas untuk pendirian tempat ibadah dan sosial keagamaan. Formulasi hukum yang demikian, jelas suatu perubahan yang sangat revolusioner dan jika dapat

\footnotetext{
${ }^{1}$ Departemen Agama RI, Fiqih Wakaf (Jakarta: Direktorat Pemberdayaan Wakaf Direktorat Jenderal Bimbingan Masyarakat Islam Departemen Agama RI, 2007), 1.

${ }^{2}$ Abdul Halim, Hukum Perwakafan di Indonesia (Jakarta: Ciputat Press, 2005), 7.
} 
direalisasikan akan memiliki akibat yang berlipat ganda atau multiplier effect, terutama dalam kaitannya dengan pemberdayaan ekonomi umat Islam. ${ }^{3}$

Adanya perluasan harta benda wakaf yang terdapat dalam Undang-Undang Nomor 41 Tahun 2004, sejalan dengan perubahan defenisi dari wakaf itu sendiri sebagaimana yang tertuang dalam undang-undang wakaf. Dalam Undang-Undang Nomor 41 Tahun 2004 tentang Wakaf tersebut mendefinisikan bahwa:

Wakaf adalah perbuatan hukum wakif untuk memisahkan dan/atau menyerahkan sebagian harta benda miliknya untuk dimanfaatkan selamanya atau untuk jangka waktu tertentu sesuai dengan kepentingannya guna keperluan ibadah dan/atau kesejahteraan umum menurut syari'ah. ${ }^{4}$

Hal ini yang kemudian para ahli memberikan keterangan bahwa pelaksanaan wakaf dalam jangka waktu tertentu (mu'aqqot) telah dilegalkan atau telah mendapatkan pengesahan untuk dilakukan di Indonesia. ${ }^{5}$ Perluasan objek wakaf yang terdapat dalam Undang-Undang Nomor 41 tahun 20004 tentang Wakaf, perluasan objek wakaf yang dimaksud adalah kedudukan Hak Atas Kekayaan Intelektual (HAKI) sebagai harta benda wakaf. Hal ini dapat dicermati secara jelas dalam pasal 16 ayat (3) yang berbunyi: Benda bergerak sebagaimana dimaksud pada ayat (1) huruf b adalah harta benda yang tidak bisa habis karena dikonsumsi, meliputi: (a) uang; (b) logam mulia; (c) surat berharga; (d) kendaraan; (e) hak atas kekayaan intelektual; (f) hak sewa; dan (g) benda bergerak lain sesuai dengan ketentuan syariah dan peratura perundang-undangan yang berlaku. ${ }^{6}$

Perluasan obyek wakaf yang tertuang dalam pasal 16 undang-undang wakaf tersebut dapat dilihat bahwa HAKI menjadi salah satu benda bergerak yang dapat dijadikan sebagai obyek pelaksanaan perwakafan di Indonesia. HAKI atau Intellectual Property Rights (IPR) adalah kekayaan tidak berwujud (intangble) hasil olah pikir atau kreativitas manusia yang menghasilkan suatu ciptaan atau invensi di bidang seni,

\footnotetext{
${ }^{3}$ Abdul Haris Naim, "Pengembangan Objek Wakaf dalam Fiqih Islam dan Hukum Positif di Indonesia" Jurnal Zakat dan Wakaf: ZISWAF, Vol. 4, No. 2, Desember 2017, 246.

${ }^{4}$ Republik Indonesia, Undang-Undang Nomor 41 Tahun 2004 tentang Wakaf, Pasal 1 ayat (2).

${ }^{5}$ Direktorat Pemberdayaan Wakaf, Proses Lahirnya Undang-Undang Nomor 41 Tahun 2004 tentang Wakaf(Jakarta: Departemen Agama RI, 2005), 21.

${ }^{6}$ Republik Indonesia, Undang-Undang Nomor 41 Tahun 2004 tentang Wakaf, Pasal 16 ayat (3)
} 
sastra, ilmu pengetahuan dan teknologi yang mempunyai manfaat ekonomi. Pengertian tersebut sebada dengan pendapat dari Rahmadi Usman sebagaimana dikutip Imaniyati dan Agus yang mendefenisikan HAKI sebagai hak atas kepemilikan terhadap karyakarya yang timbul atau lahir karena adanya kemampuan intelektualitas manusia dalam ilmu pengetauan dan teknologi. ${ }^{7}$ Jadi HAKI terdapat hak yang memiliki nilai ekonomis yang secara hukum diberikan oleh undang-undang kepada seorang pencipta atau penemu atas suatu karya yang lahir dari kemampuan intelektual manusia.

Pengembangan objek wakaf menunjukan dua hal, yaitu: Pertama, obyek wakaf itu sudah ada ketentuannya dalam berbagai kitab fikih dengan pendapat yang beragam dan dalam berbagai peraturan perundang-undangan yang dibentuk oleh pemerintah; Kedua, perkembangan teknologi dan peradaban manusia mendorong adanya perubahan cara pandang yang berimbas pada perluasan pemaknaan harta (al-māl), sehingga pengembangan obyek wakaf dipahami sebagai perluasan cakupan benda wakaf yang sudah dijelaskan oleh ulama sebelumnya. ${ }^{8}$

Perkembangan perwakafan yang terjadi di Indonesia mengarahkan kepada masyarakat untuk menuju era wakaf produktif. Wakaf tidak lagi hanya sebatas tanah yang seringkali tidak bernilai produktif. Wakaf harus dipayakan untuk sebesarbesarnya demi kemaslahatan ummat. Salah satu bentuk wakaf produktif yang masih jarang terfikirkan oleh wakif maupun nadir adalah Wakaf Hak Atas Kekayaan Interlektual (HAKI). ${ }^{9}$

Salah satu bentuk benda wakaf yang masuk kategori benda bergerak dan tidak berwujud adalah Hak Atas Kekayaan Intelektual (HAKI). HAKI meskipun bukan hal baru, namun masih asing bagi sebagian besar masyarakat di Indonesia. Mengingat HAKI memang berasal dari peradaban masyarakat Barat yang sarat akan nilai-nilai individualistik-kapitalistik, sehingga ketika diundangkan bahwa HAKI merupakan

\footnotetext{
${ }^{7}$ Neni Sri Imaniyati, Panji Adam Putra Agus, Hukum Bisnis (Bandung: PT Refika Aditama, 2017), 150

${ }^{8}$ Muh. Hasbi Ash Shiddiq, "Hak Atas Kekayaan Intelektual sebagai Objek Wakaf dalam Konteks Fiqh dan Hukum Positif," Al-Syakhshiyyah: Jurnal Hukum Keluarga Islam dan Kemanusiaan, Vol. 1 No. 2, 2019; 129.

${ }^{9}$ Eva Mir'atun Niswah, "Problematika Yuridis Wakaf Hak Kekayaan Intelektual di Indonesia," Volksgeist, Vol. 1, No. 2 Desember, 2018; 125.
} 
salah satu benda wakaf, masyarakat tidak terlalu merespon. Faktanya, hingga saat ini bentuk wakaf HAKI masih sangat jarang ditemui. ${ }^{10}$

HAKI adalah bagian dari benda, lebih tepatnya termasuk ke dalam jenis benda yang tidak berwujud (benda immateril). ${ }^{11}$ Jika dilihat dari peraturan perundangundangan di Indonesia yang mengatur tentang HAKI dapat beralih atau dialihkan, baik seluruhnya maupun sebagian karena pewarisan, hibah, wasiat, perjanjian tertulis atau sebab-sebab lain yang dibenarkan oleh peraturan perundang-undangan, hal ini juga termasuk dapat diwakafkan. Oleh karena itu artikel ini memberikan gambaran secara yuridis mengenai kedudukan HAKI sebagai obyek wakaf.

\section{B. Hak Atas Kekayaan Intelektual (HAKI) sebagai Benda Immateril}

Pembahasan HAKI erat kaitannya atau dipengaruhi oleh pemikiran John Locke yaitu tentang hak milik. Locke berpendapat bahwa hak kepemilikan terhadap benda oleh seorang manusia yang dihasilkannya itu sudah ada sejak manusia lahir. Benda yang dimaksud di sini bukan hanya terkait dengan benda yang berwujud, akan tetapi termasuk juga benda yang abstrak. Oleh karena itu, yang disebut dengan hak kepemilikan manusia terhadap benda yang tidak berwujud lahir atau merupakan hasil dari intelektualitas manusia. ${ }^{12}$ Dari hasil kerja berpikir (intellectual) seseorang adalah ide atau gagasan yang kemudian diterapkan dalam sebuah bentuk ciptaan atau temuan. Oleh karena itu, dalam ide atau gagasan tersebut telah melekat predikat intelektual yang bersifat abstrak.

Secara yuridis dengan berdasar pada Kitab Undang-Undang Hukum Perdata (KUHPerdata), kebendaan diatur dalam Buku Kedua KUHperdata. Menurut Pasal 499 KUHPerdata yang dimaksud dengan benda adalah setiap barang dan hak yang dapat dikuasai dengan hak milik. Barang yang dimaksud oleh Pasal 499 KUHPerdata

\footnotetext{
${ }^{10}$ Ibid., 124.

${ }^{11}$ Khoirul Hidayah, Hukum HKI di Indonesia Kajian Undang-Undang dan Integrasi Islam (Cet. 2; Malang: UIN Malik Press, 2013), 2.

${ }^{12}$ Tomi Suryo Utomo, Hak Kekayaan Intelektual (HKI) di Era Global: Sebuah Kajian Kontemporer (Yogyakarta: Graha Ilmu, 2009), 10.
} 
tersebut adalah benda materiil (stoffelijk voorwerp), sedangkan hak adalah benda immateriil. ${ }^{13}$ Oleh karena itu, benda diklasifikasikan kedalam benda yang berwujud dan yang tidak berwujud. Yang dimaksud dengan benda berwujud adalah benda yang bisa dilihat serta diraba melalui panca indera manusia misalnya seperti kursi, meja dan sebagainya. Sedangkan yang dimaksud dengan benda tidak berwujud ialah benda yang tidak bisa diraba atau ditangkanp oleh panca indera manusia dan merupakan hasil pemikiran dari manusia.

HAKI merupakan hak yang muncul dari hasil kreasi manusia degan menggunakan kemampuan otaknya untuk menciptakan sebuah produk atau sesuatu yang berguna untuk manusia. Karena berasal dari hasil kemampuan otak atau pikiran, maka HAKI sering digolongkan sebagai sebuah hak atas barang tidak berwujud. Namun terkadang HAKI digolongkan sebagai hak atas benda berwujud apabila kreasi dari ide-ide seseorang dituangkan dalam bentuk karya seperti ciptaan kesusasteraan, buku, prototipe mesin/robot, karya-karya dalam bidang pengetahuan dan teknologi atau hal lain sejenisnya yang memiliki nilai manfaat untuk manusia. ${ }^{14}$

Masuknya HAKI ke dalam kategori hukum benda karena adanya kepemilikan terhadap hak-hak kebendaan yang melekat didalamnya dan dapat dimiliki secara mutlak (absolut), sehingga dalam hal ini HAKI kemudian bisa juga diperalihkan kepemilikannya dengan cara transaksi seperti jual beli, pewarisan, dilisensikan atau dialihkan sesuai dengan cara-cara yang dibenarkan oleh peraturan perundangundangan.

Hak yang melekat didalam HAKI adalah hak eksklusif. Hak eksklusif adalah hak untuk mengecualikan pihak lain dalam jangka waktu tertentu dengan memperhitungkan pembatasan yang berlaku. Defenisi yang dikemukakan tersebut memiliki tajuan agar dapat memberikan perlindungan atas kreasi intelektual dari

\footnotetext{
${ }^{13}$ OK Saidin, Aspek Hukum Hak Kekayaan Intelaktual (Jakarta: Raja Grafindo Persada, 2003), 12.

${ }^{14}$ Muh. Hasbi Ash Shiddiq, "Hak Atas Kekayaan Intelektual sebagai Objek;" 134.
} 
tindak pembajakan atau pemalsuan. ${ }^{15}$ Pada dasarnya hak kebendaan berkaitan dengan hak kepemilikan, sehingga kepemilikan selalu memiliki keterkaitan dengan bendabenda baik secara materiil maupun immaterial. ${ }^{16}$

Secara umum HAKI terbagi dalam dua kategori yaitu: (1) hak cipta; dan (2) hak kekayaan industri meliputi: (a) paten; (b) merek; (c) desain industri; (d) desain tata letak sirkuit terpadu; (e) rahasia dagang; dan (f) indikasi geografis. Mencermati pembagian di atas, HAKI secara umum berkaitan dengan ciptaan dan kekayaan industri dan mempunyai nilai komersial. Merek dan paten sebagai bagian produk karya intelektual selalu dianggap sebagai suatu aset komersial yang dimiliki oleh perusahaan, oleh karena itu diperlukan adanya perlindungan hukum terhadap karya-karya intelektualitas seseorang. ${ }^{17}$

HAKI merupakan suatu hak milik (property) dalam ranah hukum kebendaan, oleh karena terdapat dua sisi yang berkaitan yaitu aspek yuridis dan aspek ekonomis. Yang pertama berkaitan dengan aspek yuridis, Secara yuridis penggunaan kaya atau istilah kekayaan berkaitan dengan kepemilikan hak atas benda bergerak (moveable goods), benda tidak bergerak (immoviable goods) benda yang berwujud (tangiable goods), dan tidak berwujud (intangiable goods). Dari perspektif hukum HAKI termasuk atau tergologolong sebagai hak milik pribadi (personal property) yang lahir dari hak alamiah manusia (natural right) sehingga HAKI sama seperti hak kebendaan lainnya yang dapat dipertahankan dari penguasaan siapapun yang tidak berhak atas hak tersebut. ${ }^{18}$

\footnotetext{
${ }^{15}$ Rahmi Jened, Hak Kekayaan Intelektual Penyalahgunaan Hak Eksklusif (Surabaya: Airlangga University Press, 2007), 4.

${ }^{16}$ Misbahul Anam, "Diskursus HAKI sebagai Harta Wakaf dalam Perspektif Hukum Ekonomi Islam," dalam http://kompasiana.com/anam_1986/54f5d185a33311b5538b4617/diskursus-hakkekayaanintelektual-sebagai-harta-wakaf-dalam-perspekttif-hukum-ekonomi-islam diakses tanggal 10 Oktober 2020

${ }^{17}$ Saidin, Aspek Hukum Hak Kekayaan Intelaktual, 18.

${ }^{18}$ Pipin Syarifin dan Dedah Jubaedah, Peraturan Hak Kekayaan Intelektual di Indonesia (Bandung: Pustaka Bani Quraisy, 2004), 166.
} 
Berdasarkan sejarah kelahirannya HAKI merupakan bentuk baru dari pengembangan hak milik konvensional atau benda bergerak yang tidak berwujud (intangible property) kebendaan HAKI muncul sebagai bentuk penghargaan (reward) atas kegiatan intelektual yang lahir dari pemikiran manusia (mental labour) untuk mewujudkan suatu yang baru atau orisinil, baik dibidang ilmu pengetahuan, teknologi, sastra serta dalam bidang industri. Pertama, dilihat dari segi bentuk dan sifatnya, HAKI tergolong sebagai benda bergerak tak berwujud (intangible goods), sehingga sifat tersebut memerlukan adanya perlindungan hukum HAKI, perlindungan tersebut bukan ditunjukan terhadap benda berwujud akan tetapi pada sesuatu yang bersifat abstrak yang terkandung dalam benda berwujud tersebut. ${ }^{19}$ Disamping terdapat perbedaan antara HAKI dengan hak kebendaan yang pada umumnya, terdapat persamaan antara HAKI dengan hak kebendaan yaitu hak kebendaan dan HAKI bisa beralih kepada orang lain dengan berbagai cara atau peristiwa hukum diantaranya seperti pewarisan, perjanjian jual beli, hibah dan sebagainya sepanjang peralihan tersebut tidak bertentangan dengan ketentuan peraturan perundang-undangan yang berlaku dalam masyarakat.

Kedua, dilihat dari segi ekonomis melekat hak ekslusif dalam HAKI yang memiliki berfungsi untuk memberikan pelegalan terhadap pemiliknya untuk memanfaatkan penggunaannya. Dari aspek ekonomis kepemilikan atas kekayaan intelektuall lebih bersifat industrialis daripada sebagai personal property. Oleh karena itu hak ekslusif atas suatu kekayaan intelektual dapat dimanfaatkan atau digunakan oleh orang lain dengan perjanjian lisensi dengan cara seorang penerima lisensi harus membayar royalty kepada pemiliknya selaku pemegang hak atas kekayaan intektual tersebut. Jadi, esensi mendasar dari HAKI didasarkan atas suatu pandangan bahwa karya-karya intelektual yang dihasilkan oleh seseorang, dalam proses pembuatannya pasti membutuhkan skill atau suatu keahlian khusus serta dibutuhkan juga keuletan.

\footnotetext{
${ }^{19}$ Ibid., 167.
} 
Kepemilikan atas HAKI bersifat abstrak, jika dibandingkan dengan hak kepemilikan benda yang terlihat, akan tetapi hak-hak tersebut sama halnya hak-hak benda, karena hak tersebut bersifat mutlak. ${ }^{20}$ Inilah yang kemudian memposisikan penggolongan hak atas kekayaan intelektua tersebut ke dalam hukum harta benda.

Menurut Konvensi World Intellectual Property Organization (WIPO), HAKI disebut sebagai hak milik intelektual karena memasukkan hak-hak yang berkaitan dengan karya sastra, karya seni dan hasil karya ilmiah, invensi-invensi di semua bidang usaha manusia, penemuan ilmiah, desain industri, merek dagang, merek jasa, dan nama-nama dalam penandaan-penandaan komersial, perlindungan terhadap persaingan tidak sehat, dan seluruh hak lain hasil dari aktivitas intelektual yang berhubungan dengan industri, karya ilmiah, karya sastra, dan bidang-bidang seni. ${ }^{21}$ Oleh karena itu Hak Atas Kekayaan Intelektual merupakan pengakuan dan pengahargaan pada seseorang ataupun badan hukum karena penemuannya atau hasil karya intelektualnya, dengan cara memberikan hak-hak khusus bagi mereka baik yang bersifat ekonomis maupun sosial. $^{22}$

Jadi bisa dikatakan HAKI termasuk kedalam hukum harta benda karena terdapat beberapa elemen penting yang merupakan bagian atau yang melekat pada HAKI, diantaranya: adanya sebuah hak eksklusif yang diberikan oleh hukum; hak tersebut lahir dari usaha manusia dengan berdasar atas kemampuan intelektual; hasil kerja intelektual tersebut bernilai ekonomi; dan dapat dialihkan.

\section{Peraturan Pelaksanaan Wakaf di Indonesia}

Peraturan pelaksanaan kegiatan perwakafan di Indonesia telah mengalami beberapa perubahan, hal ini dikarenakan pemerintah terus melakukan upaya untuk meningkatkan pelaksanaan kegiatan perwakafan yang bertujuan untuk kemajuan

\footnotetext{
${ }^{20}$ Adrian Sutedi, Hak Atas Kekayaan Intelektual (Jakarta: Sinar Grafika, 2013), 13.

${ }^{21}$ Ibid., 14.

${ }^{22}$ Suyud Margono dan Amir Angkasa, Komersialisasi Aset Intelektual - Aspek Hukum Bisnis, (Jakarta: Grasindo, 2002), 24.
} 
perekonomian umat. Jika melihat pada sejarahnya, peraturan perwakafan telah ada sejak masa kolonialisme di Indonesia. Pada masa penjajahan pemerintah Kolonial Belanda telah mengeluarkan beberapa peraturan untuk mengatur pelaksanaan wakaf pada masa itu di antaranya:

1) Surat Edaran Sekretaris Governemen pertama tanggal 31 Januari 1905 No. 435 sebagaimana termuat dalam Bijblad 1905 No. 6196;

2) Surat Edaran Sekretaris Governemen tanggal 4 Januari 1931 No. 361/A yang dimuat dalam Bijblad 1931 No 125/A;

3) Surat Edaran Sekretaris Governemen tanggal 24 Desember 1934 No. 3088/A sebagaimana termuat dalam Bijblad tahun 1934 No. 13390, dan;

4) Surat Edaran sekretaris Governemen tanggal 27 Mei 1935/A sebagaimana termuat dalam Bijblad tahun 1935 No. 13480. ${ }^{23}$

Akan tetapi peraturan pelaksanaan wakaf yang dibuat pada masa penjajahan tidak berjalan sebagaimana mesetinya, melainkan hanya untuk keinginan politik yang tidak jujur serta dilandasi dengan pemahaman yang tidak benar mengenai hakikat wakaf yang sebenarnya. Akibatnya adalah peraturan pelaksanaan yang dibuat terkait pelaksanaan wakaf tersebut, tidak memiliki pengaruh terhadap pengembangan wakaf, hanya difungsikan untuk memenuhi tata aturan administrasi wakaf saja. Hal ini tentu dipengaruhi oleh, keinginan penjajah yang sangat sulit untuk memakmurkan serta memberdayakan rakyat yang di tanah jajahannya. ${ }^{24}$ Akan tetapi, Peraturan mengenai perwakafan tanah yang dikeluarkan pada masa penjajahan Belanda tersebut, terus berlaku atau masih dipergunakan setelah Indonesia merdeka. Hal ini didasarkan atas ketentuan pasal 2 Aturan Peralihan Undang-Undang Dasar 1945 (UUD 1945) yang memuat ketentuan bahwa selam belum diadakan atau diundangkan peraturan perundang-undangan yang baru berdasarkan UUD 1945 ini, maka badan negara ataupu

\footnotetext{
${ }^{23}$ Wawan Hermawan, "Politik Hukum Wakaf di Indonesia," Jurnal Pendidikan Agama Islam: Ta'lim, Vol. 12 No. 2, 2014; 151.

${ }^{24}$ Ibid.
} 
peraturan yang lama masih tetap dipakai atau berlaku sampai pemerintah mengeluarkan peraturan-perundangan yang baru.

Regulasi wakaf menunjukan perkembangan kearah positif setelah Indonesia merdeka, lebih tepatnya dirasakan setelah lima bulan Indonesia merdeka. Tepat pada tanggal 3 Januari 1946, Pemerintah mendirikan Kementerian Agama yang ditetapkan berdasarkan pada penetapan Presiden RI Nomor I/SD/1946. Setelah itu juga, Pemerintah mengeluarkan PP No 33 Tahun 1949 Jo PP No 8 Tahun 1950 dan PMA Nomor 9 dan 10 Tahun 1952. Rachamdi Usman dalam bukunya menjelaskan bahwa, dalam peraturan tersebut menegaskan kehadiran Departemen Agama beserta segala bentuk lembaga yang berada dibawahnya memiliki berkewajiban untuk melakukan penyelidikan, penentuan, pendaftaran serta pengawasan terhadap pemeliharaan harta wakaf (khusus benda tak bergerak dalam bentuk tanah dan bangunan masjid). ${ }^{25}$ Pada tanggal 8 Oktober 1956 Jawatan Urusan Agama mengeluarkan Surat Edaran Nomor 5/D/1956 yang mengatur tentang Prosedur Perwakafan Tanah. Peraturan ini bertujuan utntuk mempertegas serta malukaukan tindak lanjut terhadap peraturan-peraturan yang telah ada di masa Kolonial Belanda yang dalam hal ini tidak memberi kepastian hukum tentang tanah-tanah wakaf di Republik Indonesia.

Kemudian Jawatan Urusan Agama/Kementerian Agama juga melakukan pembenahan terhadap pengaturan di luar Jawa-Madura dan Yogyakarta-Surakarta yang tidak terakomodir dalam aturan pada masa pemerintah Kolonial Belanda. Pengaturan mengenai perwakafan untuk kedua wilayah tersebut, baru diundangkan atau diatur dalam peraturan setelah sepuluh tahun Indonesia merdeka. Pengaturan wakaf di wilayah luar Jawa-Madura mendapatkan kepastian hukum setelah Pemerintah Indonesia mengeluarkan Surat Edaran Jawatan Urusan Agama Nomor 5/D/1955. Dalam Surat Edaran tersebut memberikan kewenangan sepenuhnya kepada Kantor Urusan Agama Provinsi-provinsi yang belum dicakup oleh peraturan wakaf

\footnotetext{
${ }^{25}$ Rachmadi Usman, Hukum Perwakafan di Indonesia (Jakarta: Sinar Grafika, 2009), 10.
} 
sebelumnya supaya melakukan musyawarah dengan para gubernur, melakukan pendaftaran wakaf harta dengan mengacu kepada prosedur dan peraturan yang telah ada yang telah dikeluarkan oleh Jawatan Urusan Agama. sementara pengaturan wakaf untuk Wilayah Daerah Istimewa Yogyakarta baru ada setelah dikeluarkannya Surat Petunjuk Kantor Urusan Agama Daerah Istimewa Yogyakarta Nomor I/P.W/58 tentang Pelaksanaan Pendaftaran Tanah-Tanah Wakaf di Daerah Istimewa Yogyakarta. Demikianlah sampai Tahun 1950-an pengaturan wakaf sudah mencakup seluruh provinsi yang ada di Indonesia. Selain itu, ada perubahan prosedur dan pihak-pihak. ${ }^{26}$

Pemerintah Republik Indonesia terus menuruh perhatian terkait dengan perlindungan tanah wakaf, sehingga dicantumkan secara tertulis dalam UndangUndang Nomor 5 Tahun 1960 tentang Peraturan Dasar Pokok Agraria. Keberadaan dari UUPA memiliki tujuan untuk merubah peraturan-peraturan tentang agraria pada masa penjajahan atau masa kolonial. Perubahan bukan saja dilakukan untuk bidang hukum pertanahan saja, melainkan dalam berbagai bidang hukum positif lainnya juga. ${ }^{27}$ Mengenai politik hukum agraria nasional antara lain disebutkan dalam konsiderans huruf a, yang secara garis besar menegaskan terkait dengan segala pertimbanganpertimbangan mengenai perlu adanya hukum agraria nasional. Hukum agraria nasional adalah hukum agraria didasarkan atas hukum adat yang berkaitan dengan tentang tanah, hukum yang sederhana serta peraturan yang adanya menjamin kepastian hukum bagi seluruh rakyat Indonesia, selain itu juga hukum agraria nasional tidak juga mengabaikan segala unsur-unsur yang bersandar pada hukum atau aturan agama.

Konsideran tersebut secara yuridis masukan kedalam ketetuan pasal 5 UndangUndang Pokok Agraria Nasional, dalam pasal tersebut menegaskan bahwa hukum agraria nasional yang dikeluarkan berlaku atas bumi, air dan ruang angkasa ialah hukum adat, sepanjang tidak bertentangan dengan kepentingan nasional maupun

\footnotetext{
${ }^{26}$ Republik Indonesia, Peraturan Pemerintah Nomor 28 Tahun 1977 tentang Perwakafan Tanah Milik, Bagian Menimbang.

${ }^{27}$ Heru Susanto, "Sejarah Perkembangan Perundang-Undangan Wakaf di Indonesia," Bilancia, Vol. 10, No. 2, Juli - Desember 2016; 71.
} 
negara, kemudian harus berdasar pada asas persatuan bangsa, sosialisme Indonesia dan peraturan-peraturan yang tercantum dalam undang-undang ini maupun dengan peraturan perundangan lainnya, dan juga segala sesuatu dengan memperhatikan segala unsur-unsur yang bersandar pada hukum agama.

Setelah Pemerintah memberikan jaminan perlindungan hukum terhadap wakaf, pelaksanaan kegiatan perwakafan semakin mendapatkan tempatnya. Hal ini dapat dilihat dari Pemerintah mengeluarkan Peraturan Perwakafan Tanah Milik Nomor 28 Tahun 1977 bertepatan pada tanggal 17 Mei 1977. Ada beberapa hal yang melatarbelakangi atau yang menjadi pertimbangan untuk dikeluarkan Peraturan Pemerintah tersebut sebagai berikut:

a. Bahwa wakaf merupakan kegiatan keagamaan yang dapat dimanfaatkan untuk sarana pengembangan kehidupan keagamaan, dalam hal ini bagi mereka yang beragama Islam. Selain itu juga kegiatan perwakafan dapat meningkatkan kesejahteraan secara materiil dan kesejahteraan secara spriritual, yang mengantarkan masyarakat untuk menuju kehidupan yang makmur dan adil yang berdasar pada pancasila;

b. Mempertimbangkan bahwa pengaturan perundang-undangan yang brelaku sekarang, dalam hal ini yang mengatur terkait wakaf tanah milik harus diubah. Alasannya karena selain belum memenuhi secara tepat segala kebutuhan yang berakaitan dengan cara-cara perwakafan, dinilai belum efektif untuk membuka ruang terhadap kemungkinan munculnya beberapa hal yang tidak diinginkan terjadi, karena belum adanya data-data yang lengkap dan nyata berkaitan dengan tanah-tanah yang diwakafkan. ${ }^{28}$

Ketentuan Peraturan Pemerintah Nomor 28 Tahun 1977 Pasal 17 ayat (1) yang mengatur tentang Perwakafan Tanah Milik, menjelaskan terkait dengan seluruh peraturan yang mengatur tentang perwakafan sebagaimana yang terdapat dalam

\footnotetext{
${ }^{28}$ Ibid, 74.
} 
ketentuan Blijblad Nomor 6196 Tahun 1905, dan Bijblad Nomor 12573 Tahun 1931, kemudian terdapat juga dalam ketentuan Bijblad Nomor 13480 Tahun 1935 beserta berbagai ketentuan terkait dengan pelaksanaannya apabila bertentangan dengan Peraturan Pemerintah Nomor 28 Tahun 1977, maka peraturan tersebut dinyatakan tidak berlaku lagi. Kemudian ayat (2) menegaskan bahwa, apabila hal-hal yang belum cukup diatur dalam Peraturan Pemerintah ini, diatur lebih lanjut oleh Menteri Agama dan Menteri Dalam Negeri sesuai dengan bidangnya masing-masing. Oleh karena itu, sebagai upaya untuk menindaklanjuti dari Pasal 17 ayat (2), maka Pemerintah pada saat itu menerbitkan beberapa macam peraturan perwakafan, sebagai berikut:

1) Peraturan Menteri Dalam Negeri Nomor 6 Tahun 1977 Tentang Tata Cara Pendaftaran Tanah mengenai Perwakafan Tanah Milik.

2) PMA Nomor 1 Tahun 1978 tentang Peraturan Pelaksanaan Peraturan Pemerintah Nomor 28 Tahun 1977 tentang Perwakafan Tanah Milik.

3) Peraturan tentang Biaya dengan mengeluarkan Peraturan Kepala Badan Pertanahan Nasional Nomor 2 Tahun 1992.

4) Peraturan yang mengatur terkait Formulir dan Pedoman Pelaksanaan Peraturanperaturan tentang Perwakafan Tanah Milik yaitu Peraturan Direktur Jenderal Bimbingan Masyarakat Islam Nomor Kep/D/75/1978.

5) Peraturan yang berkaitan yang mengatut terkait dengan pendelegasian wewenang kepada Kepala Kantor Wilayah Departemen Agama Provinsi atau setingkat di seluruh Indonesia. Peraturan Keputusan Menteri Agama Nomor 73 Tahun 1978 dikeluarkan bertujuan untuk mengangkat/memberhentikan setiap Kepala Kantor Urusan Agama Kecamatan sebagai Pegawai Pencatat Akta Ikrar Wakaf (PPAIW).

6) Peraturan terkait Pembentukan Tim Koordinasi Penertiban Tanah Wakaf Seluruh Indonesia Tingkat Pusat dengan mengeluarkan Keputusan Menteri Agama Nomor 326 Tahun 1989. 
7) Peraturan yang berakaitan dengan pelaksanaan Petunjuk Pelaksanaan Keputusan Menteri Agama No. 73 Tahun 1978 dengan mengeluarkan Instruksi Menteri Agama Nomor 3 Tahun 1979.

8) Surat Direktorat Jenderal Bimbingan Masyarakat Islam (Dirjen Bimas Islam) dan Urusan Haji No. D II/5/Ed/14/1980 tanggal 25 Juni 1980 tentang Pemakaian Bea Materai.

9) Surat Dirjen Bimas Islam dan Urusan Haji No. D II/5/Ed/07/1981 tanggal 17 Februari 1981 kepada Gubernur Kepala Daerah Tingkat I di seluruh Indonesia.

10) Surat Dirjen Bimas Islam dan Urusan Haji No. D II/5/Ed/11/1981 tanggal 16 April tentang Petunjuk Pemberian Nomor Pada Formulir Perwakafan Tanah Milik.

Pelaksanaan wakaf di Indonesia menuju babak baru setelah Pemerintah mengeluarkan Undang-Undang Nomor 41 Tahun 2004 Tentang wakaf, kehadiran Undang-undang ini bertujuan untuk melakukan pembaharuan terhadap peraturan pelaksanaan wakaf di Indonesia. Pembentukan peraturan pewakafan yang baru dalam hal ini UU No 41 Tahun 2004, diawali dengan menyusun Rancangan Undang-Undang yang didasarkan atas pendapat dan analsisi dari perpektif fikih, sosiologis, serta beberapa landasan hukum yang berkaitan dengan persetujuan prakarsa penyusunan Rancangan Undang-undang Wakaf oleh Presiden. Setelah itu, kemudian Direktorat bidang pengurusan kegiatan Zakat dan Wakaf melakukan tindak lanjut dengan menyiapkan naskah akademik yang akan dijadikan sebagai landasan pikir dalam menyusun Rancangan Undang-undang tentang wakaf. ${ }^{29}$ Ide, pikiran, gagasan serta konsep yang dimuat dalam naskah tersebut, memiliki tujuan dalam mengembangkan serta meningkatkan kualitas pelaksanaan kegiatan perwakafan di Indonesia dan memperhatikan keinginan masyarakat untuk mewujudkan kesejahteranan sosial melalui kegiatan perwakafan.

\footnotetext{
${ }^{29}$ Djunaidi, Ahmad, et.al., Proses Lahirnya Undang-undang No. 41 Tahun 2004 tentang Wakaf, (Jakarta: Direktorat Pemberdayaan Wakaf Dertemen Agama RI, 2006), 37.
} 
Setelah Pemerintah mengeluarkan Undang-Undang Nomor 41 Tahun 2004 tentang Wakaf, kemudian Pemerintah mengeluarkan Peraturan Pemerintah Nomor 42 Tahun 2006 tentang Pelaksanaan Undang-Undang Wakaf tersebut. Hadirnya Perat uran Perundang-undangan wakaf beserta peraturan pelaksanaanya, menjadi satu pertanda bahwa adanya terobosan baru dalam sejarah pelaksanaan perwakafan di Indonesia. Hal ini karena di dalamnya membahas atau memuat ketentuan-ketentuan terkait wakaf yang berbeda dengan yang dipraktekan oleh masyarakat muslim Indonesia selama ini. Yang menjadikan unfang-undang wakaf yang baru berbeda dengan sebelumnya adalah hadirnya wakaf tunai dan terdapat perluasan objek wakaf, yaitu HAKI. Selain itu juga, dari segi pengertian wakaf sendiri mengalami penambahan redaksi pengertian. Hal ini dalam dilihat dalam ketentuan pasal 1 undang-undang tersebut yang memberikan pengertian tentang wakaf sebagai perbuatan hukum wakif yang memisahkan dan/atau menyerahkan sebagian harta benda yang dimiliknya agar dapat dimanfaatkan dalam jangka waktu selamanya atau dalam jangka waktu tertentu sesuai dengan peruntukannya untuk kepentingan ibadah dan/atau kesejahteraan umum menurut syariah. $^{30}$

Mencermati beberapa pengertian wakaf di atas dapat diketahuai pembaharuan makna wakaf itu sendiri yaitu wakaf bisa dilakukan dalam jangka waktu tertentu. Kemudian dalam pasal 15 undang-undang wakaf telah mengklasifikasikan benda wakaf menjadi benda yang bergerak dan benda yang tidak bergerak, benda tidak bergerak dalam undang-undang wakaf ini meliputi:

a. Hak atas tanah sebagaimana termuat dalam ketentuan peraturan perundangundangan yang berlaku, baik yang sudah didaftarkan ataupun yang belum terdaftar;

b. Bangunan atau bagian bangunan yang berdiri di atas tanah sebagaimana dimaksud pada huruf (a);

\footnotetext{
${ }^{30}$ Republik Indonesia, Undang-Undang Nomor 41 Tahun 2004 tentang Wakaf, Pasal 1.
} 
c. Tanaman dan benda lain yang berkaitan dengan tanah;

d. Hak milik atas satuan rumah susun sesuai dengan ketentuan peraturan perundangundangan yang berlaku;

e. Benda tidak bergerak lain sesuai dengan ketentuan syariah dan peraturan perundang-undangan yang berlaku. ${ }^{31}$

Sedangkan benda bergerak yang dimaksud dalam Undang-undang ini adalah harta benda yang tidak bisa habis karena dikonsumsi, meliputi: a) Uang; b) Logam mulia; c) Surat berharga; d) Kendaraan; e) Hak atas kekayaan intelektual; f) Hak sewa; dan g) Benda bergerak lain sesuai dengan ketentuan syariah dan peraturan perundangundangan yang berlaku. ${ }^{32}$ Apabila diliat lebih jauh terkait dengan beberapa pembahruan yang termuat dalam ketentuan Undang-undang Nomor 41 Tahun 2004, dapat kita menilai bahwa Undang-undang tentang wakaf tersebut telah membuka ruang bagi umat Islam agar ikut serta dalam pelaksanaan kegiatan wakaf. Undangundang ini telah memberikan kemudahan bagi mereka yang mau terlibat dengan membagi sebagian rezeki yang didapatkan untuk wakaf uang atau memberikan hak miliknya untuk dapat diwakafkan secara berjangka. Sehingga penulis menilai bahwa ini sebuah langkah yang tepat yang dilakukan oleh pemerintah dalam meningkatkan semangat wakaf di Indonesia, selain itu juga, ini adalah terobosan baru yang dapat memberikan peluang bagi peningkatan kesejahteraan umat Islam yang ada di Indonesia dan tentunya akan memberikan dampak bagi kemajuan bangsa.

\section{Konsep Yuridis Wakaf Hak Atas Kekayaan Intelektual}

Persoalan hukum Wakaf Hak Atas Kekayaan Intelektual (HAKI) tidak terlepas dari 3 bentuk, yaitu: subtansi hukum yang meliputi peraturan-peraturan yang berkaitan dengan wakaf dan HAKI, struktur hukum yang meliputi lembaga yang berkaitan dengan

\footnotetext{
${ }^{31}$ Ibid., Pasal 15.

${ }^{32}$ Ibid., Pasal 16.
} 
perwakafan dan HAKI, dan budaya hukum yang berkaitan dengan penerimaan masyarakat terhadap ketentuan-ketentuan wakaf HAKI.

Salah satu substansi lahirnya Undang-Undang Nomor 41 Tahun 2004 tentang Wakaf yaitu adanya perluasan objek wakaf. Dalam undang-undang ini menghadirkan pembaharuan wakaf dalam lingkup yang lebih luas, ini artinya objek wakaf tidak terbatas hanya pada wakaf tanah milik saja. Dalam Undang-Undang Nomor 41 Tahun 2004 terdapat perluasan harta benda wakaf yang didalamnya mengatur tentang wakaf HAKI, hal ini dapat dilihat dalam ketentuan Pasal 16 Undang-Undang No. 41 Tahun 2004 tentang Wakaf yang berbunyi:

1) Harta benda wakaf terdiri dari:
a. Benda tidak bergerak; dan

b. Benda bergerak.

2) Benda tidak bergerak sebagaimana dimaksud pada ayat (1) huruf a meliputi:

a. Hak atas tanah sesuai dengan ketentuan peraturan perundangundangan yang berlaku baik yang sudah maupun yang belum terdaftar;

b. Bangunan atau bagian bangunan yang berdiri di atas tanah sebagaimana dimaksud pada huruf a;

c. Tanaman dan benda lain yang berkaitan dengan tanah;

d. Hak milik atas satuan rumah susun sesuai dengan ketentuan peraturan perundang.undangan yang berlaku;

e. Benda tidak bergerak lain sesuai dengan ketentuan syariah dan peraturan perundang-undangan yang berlaku.

3) Benda bergerak sebagaimana dimaksud pada ayat (1) huruf b adalah harta benda yang tidak bisa habis karena dikonsumsi, meliputi:
a. Uang;
b. Logam mulia;
c. Surat Berharga;
d. Kendaraan;
e. Hak atas Kekayaan Intelektual;
f. Hak Sewa; dan
g. Benda bergerak lain sesuai dengan ketentuan syariah dan peraturan perundang-undangan yang berlaku. ${ }^{33}$

Wakaf HAKI selain diatur dalam Pasal 16 Undang-Undang Nomor 41 Tahun 2004 tentang Wakaf, juga wakaf HAKI diperjelas dalam ketentuan Pasal 21 Perat uran

\footnotetext{
${ }^{33}$ Ibid., Pasal 16.
} 
Pemerintah Nomor 41 Tahun 2006 sebagai peraturan pelaksana undang-undang wakaf. Wakaf HAKI menurut Peraturan Pemerintah tersebut termasuk kedalam kategori benda bergerak selain uang karena peraturan perundang-undangan yang dapat diwakafkan sepanjang tidak bertentangan dengan prinsip syariah. Dalam ketentuan Pasal 21 huruf b menjabarkan secara jelas tentang wakaf Hak Atas Kekayaan Intelektual yang meliputi Hak Cipta, Hak Merk, Hak Paten, Hak Desain Industri, Hak Rahasia Dagang, Hak Sirkuit Terpadu, Hak Perlindungan Varietas Tanaman dan/atau Hak lainnya. ${ }^{34}$ Dari ketentuan di atas bahwa hadirnya Undang-Undang Nomor 41 Tahun 2004 beserta peraturan pelaksanaannya memiliki tujuan selain untuk kepentingan ibadah. Pemerintah mengeluarkan undang-undang wakaf tersebut untuk dijadikan sebagai momentum pemberdayaan wakaf secara produktif untuk kepentingan sosial, hal ini dapat dilihat dari pola manajemen pemberdayaan potensi wakaf secara modern yang diatur dalam undang-undang tersebut.

Secara tekstual wakaf HAKI yang diatur dalam Undang-Undang Nomor 41 Tahun 2004 tentang Wakaf, tidak dijelaskan secara jelas dalam perundang-undangan HAKI di Indonesia. Dalam perudang-undangan HAKI yang terdiri dari Hak Cipta, Hak Merk, Hak Paten, Hak Desain Industri, Hak Rahasia Dagang, Hak Sirkuit Terpadu dan Hak Perlindungan Varietas Tanaman, memberikan ketentuan bahwa HAKI dapat beralih atau dialihkan karena pewarisan, wasiat, hibah, perjanjian, atau sebab-sebab lain yang dibenarkan oleh peraturan perundang-undangan. Misalnya terkait dengan dijelaskan dalam undang-undang tersebut hak atas merek terdaftar dapat beralih atau dialihkan karena pewarisan, wasiat, hibah, perjanjian, atau sebab-sebab lain yang dibenarkan oleh peraturan perundang-undangan. ${ }^{35}$ Akan tetapi secara yuridis wakaf HAKI walaupun tidak dijelaskan secara jelas dalam ketentuan perundang-undangan HAKI, namun kegiatan wakaf adalah perbuatan hukum yang tidak bertentangan

\footnotetext{
${ }^{34}$ Republik Indonesia, Peraturan Pemerintah Nomor 42 Tahun 2006 tentang Pelaksanaan Undang-Undang Nomor 41 Tahun 2004 tentang Wakaf, Pasal 21 huruf b.

${ }^{35}$ Republik Indoensia, Undang-Undang Nomor 15 Tahun 2001 tentang Merek, Pasal 40 ayat (1).
} 
dengan undang-undang, sehingga kata peralihan HAKI yang disebutkan dalam ketentuan perundang-undangan HAKI, menghendaki pelaksanaan wakaf HAKI yang dibenarkan oleh undang-undang.

Pasca diundangkannya Undang-Undang No. 41 Tahun 2004 tentang Wakaf, paradigma perwakafan di Indonesia mulai bergeser. Undang-undang ini dilengkapi dengan Peraturan Pemerintah No. 42 Tahun 2006 tentang Pelaksanaan UndangUndang Nomor 41 Tahun 2004 yang merupakan bagian dari semangat memperbaharui dan memperluas cakupan objek wakaf dan pengelolaannya agar mendatangkan manfaat yang maksimum, sehingga muncul istilah wakaf produktif untuk memperbaharui konsep wakaf konvensional sebelumnya.

Wakaf HAKI menghendaki adanya peralihan hak yang merupakan hak eksklusif yang dipegang oleh inventor atas hasil invensinya untuk di manfaatkan oleh nadzir. Jadi, wakaf HAKI mengedepankan Asas kemanfaatan dalam peralihan hak, untuk mengambil keuntungan ekonomis dalam bentuk hasil dari pembayaran untuk menggunakan invensi tersebut. Inilah kemudian yang menjadi landasan keberadaan benda itu sendiri sebagai harta benda wakaf, hasil ekonomi yang diperoleh dari hasil invensi tersebut dimanfaatkan sesuai dengan tujuan wakaf yang sudah dikehendaki oleh wakif tersebut, sehingga perbuatan hukum tersebut sejalan dengan pengertian wakaf yang dimuat dalam pasal 1 angka 1 undang-undang wakaf yaitu perbuatan hukum wakif untuk memisahkan dan/atau menyerahkan sebagian harta benda miliknya untuk dimanfaatkan selamanya atau untuk jangka waktu tertentu sesuai dengan kepentingannya guna keperluan ibadah dan/atau kesejahteraan umum menurut syariah. $^{36}$

Jika dalam perundang-undangan HAKI sebelumnya tidak menyebutkan secara jelas mengenai peralihan Hak Atas Kekayaan Intelektual untuk di wakafkan, maka dalam perubahan beberpa Undang-undang dibidang HAKI telah mengakomodir HAKI

\footnotetext{
${ }^{36}$ Republik Indonesia, Undang-Undang Nomor 41 Tahun 2004 Tahun 2004 tentang Wakaf, Pasal 1 Angka 1.
} 
secara jelas dalam ketentuan undang-undang HAKI diantaranya Undang-Undang Paten, Merek dan Indikasi Geografis serta Hak Cipta. Ketiga undang-undang di bidang HAKI tersebut telah memberikan kejelasan terkait dengan wakaf HAKI di dalamnya, ini artinya bahwa wakaf HAKI dianggap penting untuk meningkatkan kesejahteraan sosial. Ketentuan mengenai paralihan HAKI untuk pelaksanaan wakaf dapat dilihat dalam ketentuan beberapa perubahan undang-undang di bidang wakaf yang baru, di antaranya:

1. Undang-Undang Nomor 28 Tahun 2014 tentang Hak Cipta

Wakaf Hak Cipta termuat dalam Pasal 16 ayat (2) bahwa "Hak Cipta dapat beralih atau dialihkan, baik seluruh maupun sebagian karena: (a) pewarisan; (b) hibah; (c) wakaf; (d) wasiat; (e) perjanjian tertulis; atau (f) sebab lain yang dibenarkan sesuai dengan ketentuan peraturan perundang-undangan." 37

2. Undang-Undang Nomor 20 Tahun 2016 tentang Merek dan Indikasi Geografis

Wakaf HAKI dalam undang-undang ini diatur dalam Bab V tentang Pengalihan Hak dan Lisensi. Ketentuan tersebut termuat Pasa1 41 ayat (1) bahwa: Hak atas Merek terdaftar dapat beralih atau dialihkan karena: (a) pewarisan; (b) wasiat; (c) wakaf; (d) hibah; (e) perjanjian; atau (f) sebab lain yang dibenarkan oleh peraturan perundangundangan."38

\section{Undang-Undang Nomor 13 Tahun 2016 tentang Paten}

Wakaf Hak Paten diatur dalam Bab VII tentang Pengalihan Hak, Lisensi, dan Paten Sebagai Objek Jaminan Fidusia. Secara jelas Wakaf Hak Paten termuat dalam ketentuan Pasal 74 ayat (1) bahwa: "Hak atas Paten dapat beralih atau dialihkan baik seluruhnya maupun sebagian karena: (a) pewarisan; (b) hibah; (c) wasiat; (d) wakaf; (e)

\footnotetext{
${ }^{37}$ Republik Indonesia, Undang-Undang Nomor 28 Tahun 2014 tentang Hak Cipta, Pasal 16 ayat (2).

${ }^{38}$ Republik Indonesia, Undang-Undang Nomor 20 Tahun 2016 tentang Merek dan Indikasi Geografis, Pasal 41 Ayat (1).
} 
perjanjian tertulis; atau (f) sebab lain yang dibenarkan berdasarkan ketentuan perat uran pemndang-undangan." 39

Jika dilihat dari ketentuan pasal-pasal yang mengatur tentang wakaf HAKI dalam beberapa undang-undang di bidang HAKI tersebut, maka secara yuridis wakaf HAKI dilakukan dengan cara pengalihan hak. Pengalihan hak yang dimaksud adalah pengalihan hak ekslusif pencipta atau pemegang hak untuk mendapatkan manfaat ekonomi atas ciptaan. Sehingga yang dimanfaatkan dari wakaf HAKI adalah manfaat ekonomi yang bisa digunakan untuk memenihi kebutuhan sosial. Oleh karena itu, ketentuan mengenai peralihan HAKI untuk diwakafkan, memiliki dasar hukum yang dapat dibenarkan sesuai dengan peraturan perundang-undangan yang berlaku, baik dari segi undang-undang perwakafan maupun undang-undang di bidang HAKI.

\section{E. Kesimpulan}

Wakaf HAKI secara yuridis telah mendapatkan legitimasi hukum di Indonesia., yaitu diatur di dalam Undang-Undang Nomor 41 Tahun 2004 tentang Wakaf. Wakaf HAKI juga telah ditegaskan dalam Undang-undang di bidang HAKI, baik sebelum undang-undang wakaf dikeluarakan maupun sesudah undang-undang wakaf dikeluarkan. Tata cara pelaksanaan wakaf HAKI diatur dalam undang-undang secara umumnya. Didalam undang-undang di bidang HAKI mengatur tentang wakaf HAKI dilakukan dengan cara peralihan hak untuk mendapatkan manfaat ekonomi (hak ekslusif). Alasan yang paling mendukung terkait dengan wakaf HAKI adalah HAKI masuk kedalam kategori hak kebendaan, sehingga jika hak kebendaan bisa beralih kepada orang lain dengan berbagai cara atau peristiwa hukum diantaranya seperti pewarisan, perjanjian jual beli, hibah termasuk wakaf.

HAKI bisa beralih juga sepanjang peralihan tersebut tidak bertentangan dengan ketentuan peraturan perundang-undangan yang berlaku dalam masyarakat termasuk salah satunya dengan cara wakaf. Hal dikarenakan HAKI termasuk benda bergerak yang tidak berwujud (intangible property), kebendaan HAKI muncul sebagai bentuk

\footnotetext{
${ }^{39}$ Republik Indonesia, Undang-Undang Nomor 13 Tahun 2016 tentang Paten, Pasal 74 Ayat (1).
} 
penghargaan (reward) atas kegiatan intelektual yang lahir dari pemikiran manusia (mental labour) untuk mewujudkan suatu yang baru atau orisinil, baik di bidang ilmu pengetahuan, teknologi, sastra serta dalam bidang industri.

\section{Daftar Pustaka}

Ahmad, Djunaidi, et.al. Proses Lahirnya Undang-undang No. 41 Tahun 2004 tentang Wakaf. Jakarta: Direktorat Pemberdayaan Wakaf Departemen Agama RI, 2006.

Anam, Misbahul. "Diskursus HAKI sebagai Harta Wakaf dalam Perspektif Hukum Ekonomi Islam," dalam http://kompasiana.com/anam_1986/ 54f5d185a33311b5538b4617/diskursus-hakkekayaan- intelektual-sebagai-hartawakaf-dalam-perspekttif-hukum-ekonomi-islam

Ash Shiddiq, Muh. Hasbi "Hak Atas Kekayaan Intelektual sebagai Objek Wakaf dalam Konteks Fiqh dan Hukum Positif," Al-Syakhshiyyah: Jurnal Hukum Keluarga Islam dan Kemanusiaan, Vol. 1 No. 2, 2019.

Departemen Agama RI. Fiqih Wakaf. Jakarta: Direktorat Pemberdayaan Wakaf Direktorat Jenderal Bimbingan Masyarakat Islam Departemen Agama RI, 2007.

Direktorat Pemberdayaan Wakaf, Proses Lahirnya Undang-Undang Nomor 41 Tahun 2004 tentang Wakaf. Jakarta: Departemen Agama RI, 2005.

Halim, Abdul. Hukum Perwakafan di Indonesia. Jakarta: Ciputat Press, 2005.

Hermawan, Wawan. "Politik Hukum Wakaf di Indonesia," Jurnal Pendidikan Agama Islam: Ta’lim, Vol. 12 No. 2, 2014.

Hidayah, Khoirul. Hukum HKI di Indonesia Kajian Undang-Undang dan Integrasi Islam. Cet. 2; Malang: UIN Malik Press, 2013.

Imaniyati, Neni Sri, Panji Adam Putra Agus. Hukum Bisnis. Bandung: PT Refika Aditama, 2017.

Jened, Rahmi. Hak Kekayaan Intelektual Penyalahgunaan Hak Eksklusif. Surabaya: Airlangga University Press, 2007.

Margono, Suyud, dan Amir Angkasa. Komersialisasi Aset Intelektual - Aspek Hukum Bisnis. Jakarta: Grasindo, 2002. 
Naim, Abdul Haris. "Pengembangan Objek Wakaf dalam Fiqih Islam dan Hukum Positif di Indonesia" Jurnal Zakat dan Wakaf: ZISWAF, Vol. 4, No. 2, Desember 2017.

Niswah, Eva Mir'atun. "Problematika Yuridis Wakaf Hak Kekayaan Intelektual di Indonesia," Volksgeist, Vol. 1, No. 2 Desember, 2018.

Republik Indoensia. Undang-Undang Nomor 15 Tahun 2001 tentang Merek.

Republik Indonesia. Peraturan Pemerintah Nomor 28 Tahun 1977 tentang Perwakafan Tanah Milik.

Republik Indonesia. Peraturan Pemerintah Nomor 42 Tahun 2006 tentang Pelaksanaan Undang-Undang Nomor 41 Tahun 2004 tentang Wakaf.

Republik Indonesia. Undang-Undang Nomor 13 Tahun 2016 tentang Paten.

Republik Indonesia. Undang-Undang Nomor 20 Tahun 2016 tentang Merek dan Indikasi Geografis.

Republik Indonesia. Undang-Undang Nomor 28 Tahun 2014 tentang Hak Cipta.

Republik Indonesia. Undang-Undang Nomor 41 Tahun 2004 tentang Wakaf.

Saidin, OK. Aspek Hukum Hak Kekayaan Intelaktual. Jakarta: Raja Grafindo Persada, 2003.

Susanto, Heru. "Sejarah Perkembangan Perundang-Undangan Wakaf di Indonesia," Bilancia, Vol. 10, No. 2, Juli - Desember 2016.

Sutedi, Adrian. Hak Atas Kekayaan Intelektual. Jakarta: Sinar Grafika, 2013.

Syarifin, Pipin dan Dedah Jubaedah. Peraturan Hak Kekayaan Intelektual di Indonesia. Bandung: Pustaka Bani Quraisy, 2004.

Usman, Rachmadi. Hukum Perwakafan di Indonesia. Jakarta: Sinar Grafika, 2009.

Utomo, Tomi Suryo. Hak Kekayaan Intelektual (HKI) di Era Global: Sebuah Kajian Kontemporer.Yogyakarta: Graha Ilmu, 2009. 